\title{
O PŮVODU STRATEGIE
}

\section{ON THE ORIGINS OF STRATEGY}

\author{
Robert GRATTAN*
}

\begin{abstract}
Abstrakt
Text představuje fakta o dávné minulosti člověka a následně vyvozuje možný vývoj strategického myšlení. Obecné fáze vývoje člověka jsou zaznamenány, avšak vzhledem k časové a zeměpisné různorodosti tohoto vývoje je vznik strategického myšlení zkoumán s ohledem na různé formativní faktory a nikoli podle dané časové osy. $V$ rané fázi své existence se člověk soustředil na přžití, nicméně pod vlivem technologického a společenského rozvoje se mohl s védomím větš̌iho bezpeči začít dívat i do budoucnosti a pokusit se události ovlivnit, nikoli na ně pouze reagovat. Pod vlivem toho, co označujeme řeckým výrazem pleonexie, tedy neustálá chtivost, vznikly války, které se staly hlavním stimulem strategického myšlení, ačkoli nutnými předpoklady bylo rovněž použití písma a matematiky jako kognitivního rámce. Text odkazuje na moderní teorie strategií dostupné v literature pro management a sleduje paralely. Text dospívá $k$ závěru, že rozvoj strategického myšlení byl postupný a současně úzce spjatý se společenským a politickým vývojem.
\end{abstract}

\begin{abstract}
The paper assembles facts about early man's existence and then, by inference, considers how strategic thinking may have developed. The general stages of man's development are recorded but, owing to the temporal and geographical diversity of this progress, the emergence of strategic thinking is considered against various formative factors, rather than against a time-line. Man's early existence would have been concerned with survival, but, under the influence of technological and societal advances, he could, from a more secure base, begin to think into the future and to try to influence events, rather than merely react. Under the influence of what the Greeks termed pleonexia (wanting more), warfare developed and became a major stimulus for the adoption of strategic thinking, although this could not be achieved without the use of writing and mathematics to provide a cognitive framework. Throughout the paper, reference is made to modern theories of strategy as found in management literature, where parallels are observed. The paper concludes that the employment of strategic thinking was gradual, but closely allied to societal and political developments.
\end{abstract}

\section{Klíčová slova}

Teorie řízení; organizační politika; primitivní společnost; strategie; formulace strategie.

\section{Keywords}

Management theory; organisational politics; primitive society; strategy; strategy formulation.

"The reader should be warned of the hypothetical character of most of archaeologists' conclusions. Here we ask him to accept only the most probable and generally agreed deductions. Even these are at best probable."

\footnotetext{
*E-mail: Robert.Grattan@uwe.ac.uk
} 


\section{INTRODUCTION}

One understanding of strategy is that it defines the actions to be adopted to achieve a stated aim. The question here is how might this concept have been developed? The difficulty is that strategy, in some form or other, was probably employed before man discovered writing, so empirical evidence will be lacking. So, although anthropology and archaeology have revealed much information on early man, this paper has to be inferential, and will only be able to offer a plausible answer to the question posed above. Ferguson pointed out a particular error to be avoided that can occur in this approach, where, in the absence of evidence, it is argued that 'they must have' taken a particular line of action in given circumstances. ${ }^{2}$

The paper considers various factors that acted on our ancestors (and a number still act today), and that may well have encouraged strategic thinking. These factors include warfare, a familiar setting for strategy formulation, and the argument considers the context of another recognised user of strategy, namely business. This latter area is important, since most of the theorising on the subject of strategy has been conducted in this context. The paper reviews some characteristics of strategy and concludes that the factors faced by early man stimulated his development of purposive, future-orientated thinking.

\section{Periods IN EARLY History}

Man's development in early history was not a uniform progression and many variations occurred in widely separated parts of the world. A reminder of the accepted periods in early history may help to appreciate the long years of man's development during which some concept of strategy is likely to have emerged, and the accepted eras in this development are detailed at the appendix.

Since the wide variations in development make consideration of the emergence of the concept of strategy not amenable to a temporal approach, the structure here is thematic.

\section{Cognition}

Forming strategy needs analysis, thus cognition, and the identification of options leading to a decision. Cave art may be an indication of a capacity for abstract thought, but we simply cannot know how man thought at the various stages in history. The mode of thinking of early man may have been primitive, but, maybe unconsciously, he would have been constructing cognitive maps from his observed experience. De Wit and Meyer described cognitive maps as 'representations in a person's mind of how the world works. A cognitive map of a certain situation reflects a person's belief about the importance of the issues and about the issues and about the cause and effect relationship between them'.

Bentley summarised two conflicting behaviours:

- $\quad$ 'The first treats individuals as independent decision-makers who weigh costs and benefits of their options, while subject to various biases of influence...

- At the other end of the spectrum are behaviours that do not inherently 'matter', and for which there is often a large, maybe infinite, variety of options. ${ }^{, 4}$

He characterised this dichotomy as 'fashion versus reason', and man's cognitive maps may have been shaped by convention or fashion.

The individual who challenges orthodoxy on fundamentals runs risks and Jesus, Galileo and Kondratieff (who was executed by the Soviet state as recently as 1938) are examples of the price that may be exacted from radical thinkers. 'Group-think' is always the safer option. Nonetheless, the radical may succeed, given the necessary personality or power, and thus punctuate the process 
of societal change with a 'step' advance. In the main, as in modern society, much strategic change is gradual and incremental, since radical change can often be risky and controversial. ${ }^{5}$

At some stage, man hit upon the concept of 'the future'; a realisation that further separated him from his animal origins. Any time after 'now' is uncertain, and man increasingly had to try and cope with what could happen next. This thinking is at the core of strategy and, from simple and uncertain beginnings, man has refined his attempts to future-proof his intentions. This development would have taken many decades and some men would have been better at this process than others; a condition that still exists today. So Ohmae could write about acquiring a strategic cast of mind. ${ }^{6}$

Although early man faced a less-complicated environment than we do today, he was still constrained by what Simon described as 'bounded rationality'. ${ }^{7}$ The numerous factors that had to be considered militated against deriving the best solution by analysis, which leads to 'satisficing', that is adopting a decision that seems likely to achieve most of what is desired without pursuing the perfect solution. Early man could well have sought heuristics, such as 'red sky at night, etc', as a way of responding to problems he faced.

If primitive society was authoritarian, the leaders, who might be threatened by change, would not welcome the radical. Advances in technology might be more easily assimilated, however, than ideas that challenged power and politics. The acceptability of new thoughts is affected as much by who is propounding them as by their content. (In the fable, it was a child that pronounced that the king wore no clothes, and his view was discounted).

Strategy can be thought of as a mode of rational thought, in which case early man would not have been mentally equipped for such an exercise. This capability, however, would gradually have developed with writing and mathematics, but also, as we shall see, under the pressure of war.

\section{DEVELOPING SOCIETY}

Given that our simian relatives have a hierarchical structure in their groups, it would seem natural that early man, too, should have a structured, if only loosely, society. 'Alpha males' would have exercised power, which would have included making, or at least ratifying, decisions, particularly those of a vaguely strategic nature. Women, however, provided the only sure source of kinship and were also a source of power in these early groups.

The structure of families, and the very meaning of the term, is complex and underwent many changes as man developed from savagery, through barbarism to civilisation. ${ }^{8}$ The basic unit of society is the man/woman pairing that satisfies the demands of the species to reproduce, although this mode need not be monogamous, nor be a stable relationship. In time, this basic unit developed into a gens or a clan within which individuals collaborate for its greater good. (The reasons for this collaboration, however, are still being debated. ${ }^{9}$ Although more people collaborating provide greater manpower resources, they also consume more food. The early hunter/gatherers, like wild animals, will have spent their waking lives securing and consuming food, and shortages, perhaps through the winter months, threatened their very existence. Shortages might be ameliorated by moving to more favourable areas.

In time, when agriculture and the domestication of animals were practised, the families and clans became sedentary and congregated into villages, which grew into towns. This settled existence produced capital; that is, food surplus to their immediate needs which could be stored as a defence against famine, but which could also be traded. Childe also made the point that this surplus allowed societies to fund artisans, such as metal workers, who produced no food themselves. ${ }^{10}$ In such communities, specialisation and the division of labour meant that craftsmen, such as the potter or the weaver, could trade their goods for food which others had produced. This specialisation speeded up the development of technology in these settled towns, and introduced deeper changes as discussed by Patterson: 
- '...Childe viewed the rise of full-time craft specialists as part of increasing social structural differentiation, the emerging interdependency of food-producers and artisans and the growth of market exchange. The differentiation of production tasks marked the simultaneous withering away of the self-sufficiency characteristic of Neolithic (agropastoral) communities that produced a surplus and the formation of a new kind of society characterized by a division of labor and the production of goods for exchange. ${ }^{11}$

Not all those who domesticated and herded animals adopted the sedentary life and many peoples remained nomadic. They may have still hunted, but their livelihood depended on their herds. Nomadic and settled humans occupied the same regions in many cases and they did not always live peaceably together.

These developments in society were not uniform and in parts of the world different forms of society coexisted. Neanderthal man coexisted with Cro-Magnon for many centuries, and development of the Sumerians in Mesopotamia was much in advance of other races. The developments, in the main, were first-order, that is incremental, and the difficult question of how and why the society and its organisation changed is complex and largely outside the scope of this paper. There is no indication that the change was teleological, part of a life cycle or dialectical, and it most closely resembles an evolutionary process. ${ }^{12}$ The changes do not appear at this remove to have been purposive, but resemble changes brought about by developments in technology, culture, migrations, writing, etc. Furthermore, as society developed in settled communities the division of labour brought with it social stratification. If that is the case, early man cannot be seen to have evolved any strategy for his societal development: social engineering was still some centuries in the future. Robb, however, pointed out that New Archaeology now traces 'social stratification to chiefly power strategies to local, short-term political contexts. ${ }^{13}$

The argument now moves to consider various factors that were operating during these periods and developments.

\section{ENVIRONMENT AND ECOLOGY}

The modern strategist scans the environment for opportunities and for threats, but remains mindful of the uncertainty of the future. Additionally, he or she will try to make sense of what is observed. What do the signs mean? Early man was faced with the same problems, but did not yet have the analytical skills that would be developed in the coming centuries.

Early man was faced with formidable climate changes as the Ice Age came to a close and the countries of the Middle East, the cradle of civilisation, became subject to a gradual desiccation. These changes altered the distribution and behaviour of the animals he hunted, and the fertility of the soil he was beginning to till. His survival depended on his appreciation of the significance of these changes, and his ability to take an optimum course of action. For hunters, it was not too difficult, since, if the prey herds moved, man followed, but settled man had to develop irrigation techniques to cope with a drying climate.

If observation by the individual was a key skill needed, decision making and coping with change needed co-operation. Although each family or tribe would have a head, many of the elders would probably have voiced their opinions as to the optimum course of action. Co-operation, in any event, was necessary in hunting, and cave paintings depict groups of men surrounding animals, suggesting organisation. The successful hunters were those who understood the behaviour of their prey, the nature of their terrain, the vagaries of the weather, and could organise to make the kill. Those who did not acquire these skills, were, as Darwin observed, selected out. 


\section{TECHNOLOGY}

Advances in technology create options. The invention of the bow meant that the risk of attacking wild animals was reduced by the power to kill or disable at a distance, rather than attacking at close range with a club or sharpened stick. The wheel conveyed mobility and enabled heavier loads to be carried more easily. Polished stone axes permitted the felling of large trees for 'slash and burn' cultivation in forested areas. Each innovation opened new opportunities, which taxed man's ingenuity to exploit, but which also created Schumpeterian waves of creative destruction, although some stone tools continued to be used by the later, metal-equipped societies. The first metal axe rendered the stone axe undesirable, however, and the bow made redundant the sharpened stick for hunting. The wheel that made possible the farm cart also led to the chariot for war, as the simple, and later the composite, bow could kill humans as well as game. Perhaps more importantly, the domestication of animals and the invention of the wheel together conferred mobility on man which he could use for a nomadic existence, trade and war.

Primitive man's inventions stimulated his thinking on how to extract advantage from the environment, but he allowed innovations to spread readily and overlooked the competitive advantages to be gained by retaining the monopoly. In our own time, Barney and others have pointed out the advantage that can be gained through the exploitation of the firm's resources, using the resource-based view. ${ }^{14}$ We cannot know how successful man was in the early periods, but some notions of strategy were beginning to stir through the stimulus of technology.

\section{THE SUPERNATURAL}

Early man faced the vagaries of chance, as we still do today. He may have tried to link observed effects to causes, but the necessary science was not available and so he attributed the inexplicable cause to the supernatural. Frazer suggested that his response to this dilemma was first to try and influence events by practising magic, then in a later period to propitiate deities, before eventually, after many years, using science to find answers to his problems. ${ }^{15}$ The Stone Age cave paintings may be sympathetic magic, depicting the successful killing of prey as an attempt to make that desired event happen. In these early years of man's development, shamans were important and influential people in the decision-making process. Even in early Roman history the fetiales, a college of priests, figured strongly in this process:

- 'They had the task of establishing the fas [the divine law], the mystical base in the invisible world without which any enterprise commanded or authorised by ius [human law], and in more general terms any human enterprise at all, was bound to be uncertain, calamitous, even fatal' ${ }^{16}$

Even later Romans could employ the augury to make a prediction from the entrails of the sacred fowl. Strategy is essentially forward looking, so these primitive attempts to determine the future can be loosely associated with the strategy formulation process. Since we now have science for our assistance, modern strategists do not practice magic, but the basic uncertainty of the future still remains a problem.

\section{LEADERSHIP AND ORGANISATION}

A great need for the hunter/gatherer family or tribe was to coordinate their efforts to maximise their success at hunting or locating sources of food. They will have soon established that a blind rush at their prey would achieve nothing, and the hunting group would have to deploy to outwit their prey. Observation would have established that animals have keen eyesight and sense of smell, and that the approach to within arrow or spear range had to be stealthy and upwind. The best 
archers or spearmen needed to be positioned to have the optimum chance of making the kill. Some organisation and tactics were required and someone had to assume the lead.

As settlement and population increased with the use of agriculture and herding, the need for organisation increased. As Tallis observed:

- 'The need to raise and direct the labour required for economic activity, irrigation and other major public works demanded more complex forms of social organization, communication and record-keeping in the densely populated south [of Mesopotamia] than in surrounding regions. ${ }^{17}$

Kings were present in Mesopotamia when the settled population were developing towns and, then, city states. The term 'king' in the context of early man, however, is not necessarily only applied in the political sense. Frazer studied the priestly kings who were associated with primitive magic and religion, and one such, Melchizedek, king of Salem is described in the Book of Genesis 14:18 as a priest. ${ }^{18}$ Even to this day, royalty involves religious responsibilities and duties. Later kings often arose from the military, or those who gained their power from military men, and thus had to consider strategy in the context of war.

Strategy and tactics remain an issue for leaders, not necessarily for them to devise, but at least to select and endorse. We do not know how leaders were chosen in the distant past. They may have been the patriarch of the family or clan, or the strongest, dominant male. Choosing the best hunter may not have been the best solution, as modern factory experience shows that making the best worker into a foreman may lose the services of a skilled operative in exchange for gaining a poor leader. Society developed into gentile and clan groupings and Engels described the governing structure that had evolved:

- '...popular assemblies, councils of gentile chiefs and military commanders who were already aspiring to real kingly power. It was the most highly-developed constitution the gentile order could produce; it was the model constitution of the higher stage of barbarism. As soon as society passed beyond the limits for which this constitution sufficed, the gentile order was finished. It burst asunder and the state took its place. ${ }^{19}$

Organisation, however, required a sacrifice from the individual who, as Dawkins pointed out, is trying to maximise his own chances of success. ${ }^{20}$ On the other hand, the best chance of individual success may well lie in cooperation with others. In the case of strategy formulation, this is almost certainly true. The limits of individual cognition can be extended by discussion and the sharing of views, and the organisation forms of primitive man gradually extended the forum for collective decision, although the views of the many are not necessarily the right ones. Porter (1996:77) gave a modern view:

- $\quad$ 'The challenge of developing or re-establishing a clear strategy is often an organizational one and depends on leadership. With so many forces at work against making choices and tradeoffs in organizations, a clear intellectual framework to guide strategy is a necessary counterweight. Moreover, strong leaders willing to make choices are essential. ${ }^{, 21}$

It is unlikely that early man could have created a clear intellectual framework and, unless their tribal councils fulfilled that requirement, it is likely that it would have been the leaders who made the decisions.

\section{Politics}

In man's early history, whatever form of organisation was adopted, be it ever so simple, some form of politics would have been present and would have affected the choice of aims and the formulation of strategy. Once the imperatives of food and shelter had been satisfied, and 
particularly once agriculture provided retained capital to avoid a subsistence existence, more choices became available and politics developed. Pettigrew observed:

- 'Political processes in organizations evolve at the group level from the division of work in the firm, and at the individual level from associated career, reward, and status systems. ${ }^{22}$

In a similar vein, Chambers Dictionary offers two definitions for politics:

- 'The science or business of government' 'Moves and manoeuvres concerned with the acquisition of power or getting one's own way, eg in business.'

'Government', of sorts, would have been needed even when the family or kin unit predominated, but what we recognise by the term would not have been present until larger settlements and towns were created. Then, it seems, monarchs ruled who would have needed political skill to maintain sufficient support to remain in power. The king needed to develop policies, which required forward thinking with the necessity of predicting their likely outcome. Tallis described Hammurabi, King of Babylon 1792-1750 BC, as gaining success through 'a patient strategy of warfare, alliance and guile', so strategising can be recognised by us to have existed at that time. ${ }^{23}$

Aristocracies, too, developed in early society, particularly when the strategic use of warfare necessitated establishing armed forces, which needed to be led. The military gained power through the control of violence exercised on behalf of society, and also from the wealth they accumulated through looting and the capture of slaves. The aristocrats practised politics in accordance with the second definition above, and the king and his dynasty had constantly to be on guard for ambitious rivals.

Politics requires strategic thinking and the crafting of policies, and those leaders who were not able to plan and be devious would not have lasted the course. In particular war would have required the conscious use of strategy since war as Clausewitz observed: - '...is not merely an act of policy but a true political instrument, a continuation of political
intercourse, carried on with other means.'

Dynastic kingships were certainly still interested in the loot from war, but, increasingly, prestige and dominance entered into the thinking on inter-state relations. Here there is a parallel with current business concern with securing and maintaining competitive advantage, where this aim is strategy's principal concern. The result now is often the creation of business empires, and industries, as a result, becoming oligopolies. In the Neolithic period, areas of the world were dominated in turn by a few ambitious nations, who in turn declined and became themselves dominated. Strategy had widened its horizons.

The word 'strategy' has a sibling in 'stratagem' and the growing complexity of political life required more sophistication of thought in society's hierarchy of power. Leaders had to become adept at planning and forethought: Odysseus, in the Bronze Age, was noted for his guile and cunning.

\section{OPTIONS}

Strategy is, at least in part, about reviewing options and then choosing the best. We cannot know how early man conducted this process, but it will have been affected by the power relationships within the group or society. An autocratic ruler may well not welcome advice or contrary opinions, and so assumes control of the decision-making process. If he is a priestly king, the autocratic ruler can claim supernatural guidance through consultation with the deity or through the oracle. Different societies at different times will have made their decisions as dictated by their governance structure, but the more effective would have been those that considered different 
opinions and options before selecting their course of action. They would have been limited by their cognitive abilities, and were even more likely to choose the first option that seemed likely to work (the 'satisficing' behaviour discussed above).

Advances in technology created both more options and the consequent need to think through the implications. On the other hand, the invention of the wheel may just have been implemented $a d$ $h o c$, and the longer term effects on the society as a whole may have been beyond mankind at that time. Similarly, the composite bow and the spear thrower (atlatl), were used for hunting and their invention was not the cause of wars, but it would have been realised in practice how effective they were in that scenario.

Early man would have had few options, but advances in society and technology created more. The more options are available, the more flexibility is conferred, but they impose the burden of making the right choice strategically.

\section{WAR}

War is an activity that uses strategy. Indeed, business has derived many of its strategic concepts from the military. War, if it is to be other than mindless violence, is teleological and the objects of conflict in earliest times were probably looting food and material stores, or stealing wives. As agriculture and manufacture developed, enslaving defeated people to offset the shortage of labour became a prevalent object of war, and developing societies came to depend on slaves to do their necessary, routine work. Later, prestige, renown and honour came to be added to the exciting causes of war as kings became emperors and technology enabled them to embark on grandiose schemes of conquest.

War became endemic in early man's existence, although exactly when this came about is disputed. Some hold that man fought wars, albeit probably local, from earliest times, whilst others, particularly Ferguson, suggest there was a time before war. The available archaeological evidence is not convincing:

- 'A stone mace or a bronze sword indicates the presence of war, but the line between tool and weapon is often not so clear cut. The spear or arrow used to kill a beast can kill a man. ${ }^{25}$

War requires a military force, weapons, organisation, and logistics, but is fought for a purpose; an aim to be achieved. Since strategy is the way that the aim is achieved, war implies the need for a strategy, and, thus, its formulation.

Military Force. In early times, the manpower assigned to military operations had to be small, because agriculture and civil projects absorbed most of the labour available. The military, however, became the social elite and the aristocracy have based their power on their control of the society's war making machinery right up until recent times. The ruler depended on the aristocracy to fight his wars, and they exacted as their reward land and the control they could exercise over the lower orders.

Weapons. The tools used by hunters, herders and farmers were also used against humans, but, later, technology was used to improve their performance in war. The composite bow, the wheel, and the sword all improved the efficiency of soldiers and the taming of horses provided improved mobility, and, thus, manoeuvre. Nevertheless, the soldiers' skill was developed in their peacetime occupation. Thus, David, who killed Goliath the Philistines' champion with a sling stone, had learnt this skill as a shepherd protecting his flock against wild animals (1 Samuel 17:34-37). Surprisingly, military training was not given in early in the Greek and Roman civilizations, as Garlan pointed out: 
- $\quad$ 'There is a twofold reason why formal training had been either neglected or left to chance: the rudimentary expertise required of soldiers and the numerous opportunities in civilian life for initiation into the profession of arms, either through hunting (which did not differ substantially from war except in its objectives) or, especially among the Greeks, through the athletic contests and dances which played such a large part in education and religious festivals. ${ }^{26}$

Organisation. Tallis observed:

- 'In the ancient world, even more than today, the nature and structure of army, society, economy and state were directly related and interdependent. ${ }^{27}$

He suggested that the organisation of the army was modelled on the labour gangs assembled for public works in the new towns. The soldiers, who were probably not specialists but conscripted artisans, had to be divided into units under a commander, and these building blocks could be combined until the army was assembled and organised. Communication during a battle was so poor that the army commander, often the king, could not control the mass himself and had to rely on subordinate commanders to carry out his intentions. This situation suggests that a strategy, albeit rather general, had to be formed before the battle.

Logistics. The distance that armies could travel in war was limited by the means of supply of food, water and fodder. When man lived by hunting, he would have suffered the same restriction and would have learned how to support himself and his companions whilst pursuing game, perhaps for days on end, but supporting large armies in the field was a different matter. Operations over a long distance were not practical until man had tamed asses, horses, camels and oxen to carry the necessary supplies, so the nomadic herders would have had an initial advantage over the sedentary farmers and town-dwellers.

Keegan concluded that pastoralists were more warlike than the hunting and agricultural communities:

- 'It was flock management, as much as slaughter and butchery, which made the pastoralists so cold-bloodedly adept at confronting the sedentary agriculturalists of the civilised lands in battle......Working a herd...was the pastoralists' stock in trade. They knew how to break a flock up into manageable sections, how to cut off a line of retreat by circling to a flank, how to compress scattered beasts into a compact mass, how to isolate flock leaders, how to dominate superior numbers by threat and menace, how to kill the chosen few while leaving the mass inert and subject to control. ${ }^{28}$

He was drawing a parallel with military tactics, in the knowledge that the tribes of the mountains and the steppes waged wars on the settled communities, even until the Mongol invasions extending into the $15^{\text {th }}$ century AD under Timur.

Politics and war needed strategic thinking, and it is probably these activities that extended the earlier attempts at seeking advantage over the environment or other people by directed thought, as opposed to intuitive reaction. Strategy is proactive and teleological, and war would have provided a powerful stimulus to these modes of thought.

\section{STRATEGY}

One view that can be taken of strategy is that it is the imposing of the human will on the environment, and, for early man, this was his major problem. The weather, the animals that were his food supply, and his human neighbours were all outside his control. Gradually over a period, the observations of the generations may well have yielded heuristics to guide man's existential 
behaviour, and he tried to supplement them with the application first of magic and then religion, but his problems were essentially practical and the more successful were able to reason from the observed facts. If this is true, primitive forms of strategy will have emerged very early. Such attempts, however, do not accord with our contemporary view that strategy is forward looking, and they could be classified as mere problem-solving. The major problem for early man was surviving, but survival is a strategy. In the modern world, companies trading during a recession can be content, in the last resort, to survive until better trading conditions return. For primitive man, he would not have consciously formulated a strategy, but unknowingly he adopted survival.

When man discovered how to create a surplus and thus move away from subsistence, his incremental development encountered, albeit over a relatively long period, a 'step', an innovation that changed his life fundamentally. All individuals did not now have to produce the food they consumed and so society could support specialists, such as metal workers, potters, scribes, priests and the military. This specialisation led to an increase in skill levels and acceleration in technological advances, but also led to a divergence of personal aims within this developing society. For many, life became sedentary and located in towns, although substantial proportions were still nomads. Life was becoming more complicated, because the number of available options increased, and somehow choices had to be made.

The development of strategy was brought about by changes in technology, society, the environment, and the use of war, and only those states successful in that skill prospered. This process is not entirely without parallels to Darwinian evolution, and Henderson used that metaphor. ${ }^{29}$ The development of writing introduced a further dimension to the development of strategy. Writing created data, which replaced the ephemeral word of mouth and which was amenable to analysis. The meaning of the recorded facts could be discussed by the leadership and decisions on the required course of action could be recorded and distributed. Literacy was a necessary skill for formalised strategy generation, but its invention also encouraged leaders to base their decisions on fact and to extrapolate into the future.

War was probably the principal stimulus to the practice of thinking strategically. Early encounters with other groups created a contest for the available resources, but, in an under populated world, conflict could be avoided by one group moving on. The alternative was an aggressive response, using hunting tools as weapons against the intruders. The hypothesis that man is naturally aggressive has been the source of much debate in a number of disciplines such as psychology, ethnology and in anthropology, where arguments have also been used in discussions on the origins of war. These arguments can be avoided here, by considering what the aims of early man's strategy would have been. Van Wees commented on the views of classical Greece:

- 'The fundamental cause of war, as the Greeks saw it, was 'wanting more' (pleonexia). The two things of which everyone wanted were honour and wealth. ${ }^{, 30}$

The aims stated above would not have been those of primitive man, but, certainly, he would have wanted more food, better shelter, more children, warmer clothing, etc., and satisfying these needs would have been his constant preoccupation. Co-operation was a less risky strategy than conflict, but where sedentism led to the creation of towns, particularly when associated with agriculture and surplus food; it also created a target for other groups who were 'wanting more'.

Gradually, then, as man became more sophisticated, he moved from solving problems as they occurred and attempted to devise long-term aims and strategies. Short-termism is still with us, particularly at times of crisis, and it may seem expedient to find a solution in the 'garbage can' of problems and strategies as envisaged by Cohen et al..$^{31}$ 


\section{CONCLUSION}

There does not seem to be any particular point in time that early man discovered strategy, but there are indications of its partial use, or a prototype, brought about by: the start of settlement; the creation of surplus; the emergence of kings and politics, the invention of writing and the use of war as a political measure. We may view his early attempts as tactical, rather than strategic, but the dividing line between the two is arguable.

Strategy needed development of man's cognitive abilities and writing and mathematics were a considerable step forward in the collection and use of data and their analysis. The creation of surplus helped free man from some of the uncertainties of continued existence, and encourage him to think forward into the future: an essential part of the art of strategising. As the activities in towns moved away from the preoccupation with having enough to eat, strategists had to encompass many different activities and forming a synoptic view is another part of strategising.

As states were formed, rivalry led to a search for what we now call competitive advantage. If the basic drive to war is the wanting for more, the sophisticated developing states sought power, influence and honour. Such aggrandisement needed a plan, a strategy, to guide what to do next.

Early man may not have recorded his use of strategy, but from simple beginnings he gradually acquired the art. Strategising today may be greatly different from that practised by early man, but we still seek competitive advantage and embrace pleonexia.

\section{NOTES}

${ }^{1}$ CHILDE, V. G. The Prehistory of European Society, p. 14.

${ }^{2}$ FERGUSON, R. Brian. The Causes and Origins of "Primitive Warfare".

${ }^{3}$ DE WIT, Bob, MEYER, Ron. Strategy: Process, Content and Context, p. 55.

${ }^{4}$ BENTLEY, 2007, p. 1071.

${ }^{5}$ QUINN, James Brian. Strategic Change: "Logical Incrementalism".

${ }^{6}$ OHMAE, Kenichi. The Mind of the Strategist.

${ }^{7}$ SIMON, Herbert A. (1945). Administrative Behavior.

${ }^{8}$ ENGELS, Frederick (1884). The Origin of the Family, Private Property and the State in the Light of the Researches of Lewis H Morgan.

${ }^{9}$ DUBREUIL, Benoit. Strong Reciprocity and the Emergence of Large-Scale Societies.

${ }^{10}$ CHILDE, V. G. The Prehistory of European Society.

11 PATTERSON, Thomas C. Craft specialization, the reorganization of production relations and state formation, p. 308.

${ }^{12}$ NICHOLSON, Nigel (Ed.). Blackwell Encyclopaedic Dictionary of Organization Behavior.

${ }^{13}$ ROBB, John. Time and Change in Archaeological Interpretation, p. 57.

${ }^{14}$ BARNEY, Jay. Firm resources and sustained competitive advantage.

${ }^{15}$ FRAZER, John G. (1890). The Golden Bough .

${ }^{16}$ GARLAN, Yvon. War in the Ancient World: a Social History, p. 45.

${ }^{17}$ TALLIS, Nigel. Ancient Near Eastern Warfare, p. 47.

${ }^{18}$ FRAZER, John G. (1890). The Golden Bough.

${ }^{19}$ ENGELS, Frederick (1884). The Origin of the Family, Private Property and the State in the Light of the Researches of Lewis H Morgan, p. 557.

${ }^{20}$ DAWKINS, Richard (1989). The Selfish Gene, p. 69.

${ }^{21}$ PORTER, Michael. What is Strategy?, p. 77.

${ }^{22}$ PETTIGREW, Andrew. Strategy formulation as a political process, p. 81.

${ }^{23}$ TALLIS, Nigel. Ancient Near Eastern Warfare, p. 55.

${ }^{24}$ CLAUSEWITZ, Carl von (1832). On War, p. 99.

${ }^{25}$ FERGUSON, R. Brian. War before History, p. 16.

${ }^{26}$ GARLAN, Yvon. War in the Ancient World: a Social History, p. 172.

${ }^{27}$ TALLIS, Nigel. Ancient Near Eastern Warfare, p. 47. 


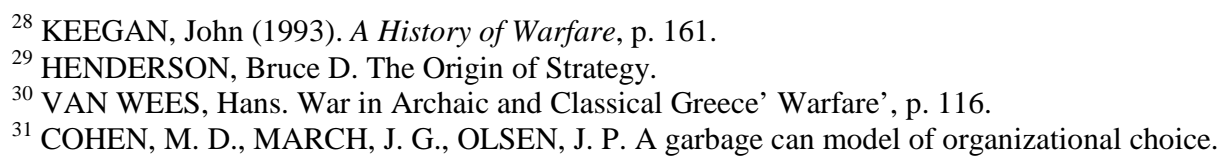

\section{LITERATURE}

[1] ARDREY, Robert. The Territorial Imperative. London: Collins, 1967.

[2] BARNEY, Jay. Firm resources and sustained competitive advantage. Journal of Management. 1991, vol. 17, no. 1, pp. 99-120.

[3] CHILDE, V. G. The Prehistory of European Society. Harmondsworth: Penguin Books, 1958.

[4] CLAUSEWITZ, Carl von (1832). On War. Edited and translated by Howard, Michael and Paret, Peter. New York: Everyman's Library, 1993.

[5] COHEN, M. D., MARCH, J. G., OLSEN, J. P. A garbage can model of organizational choice. Administrative Science Quarterly. 1972, vol. 17, pp. 1-25.

[6] DAWKINS, Richard (1989). The Selfish Gene. Oxford: Oxford University Press, 2006.

[7] DE WIT, Bob, MEYER, Ron. Strategy: Process, Content and Context. London: Thomson Learning, 2004.

[8] DUBREUIL, Benoit. Strong Reciprocity and the Emergence of Large-Scale Societies. Philosophy of the Social Sciences. 2008, vol. 38, no. 2 (June), pp. 192-210.

[9] ENGELS, Frederick (1884). The Origin of the Family, Private Property and the State in the Light of the Researches of Lewis H Morgan. In MARX, Karl, ENGELS, Frederick. Collected Works. New York: Lawrence and Wishart, 1968.

[10] FERGUSON, R. Brian. The Causes and Origins of "Primitive Warfare". Anthropological Quarterly. 2000, vol. 73, no. 3 (July), pp. 159-164.

[11] FERGUSON, R. Brian. War before History. In DE SOUZA, Philip (Ed.). The Ancient World at War. London: Thames and Hudson, 2008.

[12] FRAZER, John G. (1890). The Golden Bough. London: Macmillan, 1957.

[13] GARLAN, Yvon. War in the Ancient World: a Social History. London: Chatto \& Windus, 1975.

[14] HENDERSON, Bruce D. The Origin of Strategy. Harvard Business Review. 1989, NovDec, pp. 139-143.

[15] KEEGAN, John (1993). A History of Warfare. London: Pimlico, 2004.

[16] NICHOLSON, Nigel (Ed.). Blackwell Encyclopaedic Dictionary of Organization Behavior. Oxford: Blackwell, 1996.

[17] OHMAE, Kenichi. The Mind of the Strategist. New York: McGraw-Hill, 1982.

[18] PATTERSON, Thomas C. Craft specialization, the reorganization of production relations and state formation. Journal of Social Anthropology. 2005, vol. 5 (3), pp. 307-337.

[19] PETTIGREW, Andrew. Strategy formulation as a political process. International Studies of Management and Organizations. 1977, vol. 7, no. 2, pp. 78-87.

[20] PORTER, Michael. What is Strategy?. Harvard Business Review. 1996, Nov-Dec, pp. 61-78. 
[21] QUINN, James Brian. Strategic Change: "Logical Incrementalism". Sloan Management Review. 1978, Fall, pp. 7-21.

[22] ROBB, John. Time and Change in Archaeological Interpretation. Cambridge Archaeological Journal. 2008, vol. 18, no. 1, pp. 57-59.

[23] SIMON, Herbert A. (1945). Administrative Behavior. New York: Macmillan, 1976.

[24] TALLIS, Nigel. Ancient Near Eastern Warfare. In DE SOUZA, Philip (Ed.). The Ancient World at War. London: Thames and Hudson, 2008.

[25] VAN WEES, Hans. War in Archaic and Classical Greece' Warfare'. In DE SOUZA, Philip (Ed.). The Ancient World at War. London: Thames and Hudson, 2008.

\section{APPENDIX}

\section{Periods in Early History}

Although it is a matter of definition, the human species can be taken to have left its more animal form in the Stone Age, although its evolution was still in process. The Stone Age is usually divided into:

The Palaeolithic Period, itself divided further into:

- Lower Palaeolithic (c2,000,000 to c200,000 years BC) when stone tool began to be used.

- Middle Palaeolithic (c150,000 to c40,000 years BC) when Neanderthal Man was a hunter of mammals.

- Upper Palaeolithic (c40,000 to 10,000 years BC) when CroMagnon and Grimaldi Man used communal hunting and extensive fishing. Weapons became more refined and the atlatl (the spear thrower) was invented. Belief systems of magic and the supernatural developed.

The Mesolithic period lasted from about 10,000 to 4,000 years BC and saw the development of agriculture and animal husbandry.

The Neolithic Period saw the development of settled villages and towns dependent on domesticated plants and animals, crafts (pottery, weaving) and more sophisticated stone tools. In the Middle East, this period is quoted by some authorities as starting in 9,500 BC, showing that this classification varies in different regions according to the stage of development reached.

The Stone Age was followed by the Bronze and Iron Ages, but the defining dates and stages of development of all these periods also vary widely in different parts of the world. For instance, the Sumerians developed writing in about 3,500 BC, when bronze was available in Mesopotamia, whereas Britain did not enter the Bronze Age until about 2,300 BC.

\section{An Alternative Taxonomy}

Engels (1884: 465), completing the works of Marx, then deceased, offered an alternative, nontemporal taxonomy:

- Savagery - the period in which the appropriation of natural products, ready for use, predominated; the things produced by man were, in the main, instruments that facilitated this appropriation. 
- Barbarism - the period in which the knowledge of cattle breeding and land cultivation was acquired, in which methods of increasing the productivity of nature through human activity were learnt.

- Civilisation - the period in which knowledge of the further working up of natural products, of industry proper, and of art was acquired. 